Original Research Paper

\title{
Pemberdayaan Peternak Perempuan Melalui Transfer Teknologi Pakan Komplit
}

\author{
Sukarne $^{1}$, Muhammad Nursan ${ }^{2}$, Dahlanuddin ${ }^{3}$, Aeko Fria Utama FR ${ }^{4}$, Tarmizi $^{5}$ \\ ${ }^{1,3}$ Program Studi Peternakan, Fakultas Peternakan, Universitas Mataram, Indonesia \\ ${ }^{2,4}$ Program Studi Agribisnis, Fakultas Pertanian, Universitas Mataram, Indonesia \\ ${ }^{5}$ SPR Ridho Ilahi, Lombok Timur, Indonesia
}

https://doi.org/10.29303/jpmpi.v3i2.1037

Sitasi: Sukarne. Nursan, M., Dahlanuddin., Utama, Fr. A. F \& Tarmizi. (2021). Pemberdayaan Peternak Perempuan Melalui Transfer Teknologi Pakan Komplit. Jurnal Pengabdian Magister Pendidikan IPA 4(4)

\section{Article history}

Received: 20 September 2021

Revised: 30 September 2021

Accepted: 10 Oktober 2021

*Corresponding Author:

Sukarne, Program Studi

Peternakan, Fakultas

Peternakan, Universitas

Mataram, Indonesia

Email:sukarne1990@gmail.com

\begin{abstract}
Feed is still a major problem in the development of the livestock sub-sector. So far, farmers are still relying on animal feed needs from natural grass which causes low livestock productivity and limited livestock rearing capacity. To overcome these problems, the purpose of this community service activity is to provide training and assistance to female breeders to make complete feed and implement the use of complete feed for livestock. This training activity was carried out in Wanasaba Lauk Village, East Lombok Regency. Participants in the training activity were 15 female breeders under the Ridho Ilahi Center for Animal Husbandry. The method used in this study is the delivery of materials and the practice of making complete feeds. The training activity was carried out for 2 days and assistance for the application of complete feed technology was carried out for 3 months. The result of this training is that female farmers gain knowledge and skills in producing complete feed and in terms of capacity calculations, breeders are able to maintain a minimum of 5 heads of livestock which previously was only a maximum of 2 heads. Then in terms of productivity, average daily gain (ADG) of livestock reached 0.42 $\mathrm{Kg} /$ day.
\end{abstract}

Keywords: Complete feed, female breeder, rearing capacity.

\section{Pendahuluan}

Subsektor peternakan masih merupakan salah satu subsektor pertanian yang penting untuk dikembangkan mengingat masih banyak masyarakat bermata pencaharian sebagai pertenak, dan sebagai subsektor penghasil pangan hewani (Nursan \& Septiadi, 2020). Sebagai subsektor penghasil pangan hewani, pengembangan subsektor peternakan sangat dipengaruhi oleh beberapa faktor salah satunya faktor ketersediaan pakan. Menurut Kandalam \& Samireddypalle (2015), pakan merupakan kendala utama yang sering dihadapi oleh peternak sapi di negara-negara tropis baik di wilayah dataran tinggi maupun dataran rendah. Sementara itu ketersediaan pakan ternak ruminansia oleh peternak dipengaruhi oleh berbagai faktor seperti faktor cuaca atau iklim, ketersediaan lahan di suatu daerah (Dumont et al., 2017), jarak antara sumber pakan dan peternak, nutrisi pakan rendah, adanya musim kemarau dan sifat pakan yang kamba (Utari et al., 2012).

Desa Wanasaba Lauk Kecamatan Wanasaba Kabupaten Lombok Timur merupakan daerah yang sangat potensial untuk pengembangan ternak sapi di Provinsi Nusa Tenggara Barat. Peternakan di desa ini tidak hanya dilakukan oleh laki-laki tetapi juga dibantu oleh perempuan terutama dalam hal penyediaan pakan dan air. 
Berkaitan dengan penyediaan pakan ternak khususnya ternak sapi peternak di Desa Wanasaba Lauk masih mengalami permasalahan pakan ternak. Rata-rata peternak hanya mampu memelihara 2 ekor sapi karena harus bersusah payah mencari rumput untuk pakan ternaknya. Pakan tunggal yang mereka terapkan selama ini tidak dapat meningkatkan produktivitas ternak secara optimal. Akibatnya, kesejahteraan peternak tidak pernah bisa meningkat. Sementara itu, sangat banyak potensi lokal dari limbah pertanian, limbah perkebunan dan limbah industri yang dapat dikombinasikan menjadi pakan ternak melalui penerapan teknologi. Limbah pertanian memiliki zat adiktif sehingga bisa dimanfaatkan sebagai pakai ternak (Sari, 2016), selain limbah pertanian, limbah agroindustri juga dapat dimanfaatkan sebagai pakan khsususnya pakan komplit yang mampu mengurangi biaya produksi dan mampu meningkatkan produktivitas ternak dengan pertambahan bobot badan harian (PBB) ternak mencapai rata-rata $1.02 \mathrm{~kg}$ / hari (Mukminah et al., 2019). Oleh karena itu untuk mengatasi permasalahan pakan diperlukan suatu teknologi pakan yang dapat membantu permasalahan peternak. Salah satu teknologi pakan yang dipandang mudah, praktis, efektif dan efisien untuk diterapkan adalah teknologi pakan komplit. Pakan komplit merupakan pakan ternak ruminansia yang terdiri dari berbagai macam bahan pakan yang diformulasikan sesuai dengan kebutuhan nutrisi ternak (Baba et al., 2012).

Pakan komplit biasanya berberntuk campuran bahan pakan yang sudah diperkecil ukuran partikelnya dengan tujuan kemudahan dalam pencampuran, pengemasan, penyimpanan maupun pemberian. Karena sifatnya sebagai pakan yang dapat tersedia setiap saat maka pakan komplit biasanya dibuat dalam sediaan kering dengan kadar air di bawah $20 \%$. Akan tetapi ada kalanya kadar air pakan komplit di atas $20 \%$ namun dalam penyimpanannya menerapkan teknologi fermentasi sehingga pakan komplit tersebut harus dianginanginkan dulu sebelum pemberian pada ternak untuk mengurangi gas hasil sisa fermentasi dan menurunkan suhu akibat dari proses fermentasi. Oleh karena itu tujuan kegiatan pengabdian kepada masyarakat ini yaitu memberikan pelatihan dan pendampingan kepada peternak perempuan di Desa Wanasaba Lauk untuk membuat pakan komplit dan menerapkan penggunaan pakan komplit bagi ternak.

\section{Metode}

Kegiatan pelatihan ini dilaksanakan di sekertariat SPR Ridho Ilahi, Dusun Tanak Mira, Desa Wanasaba Lauk-Lombok Timur. Peserta aktif kegiatan pelatihan ini adalah 15 peternak perempuan (istri peternak) yang berada di bawah Sentra Peternakan Rakyat (SPR) Ridho Ilahi binaan Tarmizi, S.Pt. Kegiatan inti dari pelatihan ini dilaksanakan selama 2 hari namun sesi pendampingan penerapan teknologi dilaksanakan selama 3 bulan. Kegiatan inti dibagi menjadi 2 sesi, yaitu sesi pengayaan materi pada hari pertama dan sesi praktik pembuatan pakan komplit dilakukan di hari kedua.

Metode yang digunakan dalam pelaksanaan pengabdian ini adalah:

1. Observasi permasalahan dan potensi alternatif pemecahan masalah. Informasi permasalahan diperoleh dengan cara diskusi langsung dengan peternak, ketua kelompok maupun pendamping kelompok ternak.

2. Koordinasi dengan ketua-ketua kelompok ternak. Sebelum melakukan kegiatan, dilakukan penyamaan persepsi berkaitan dengan solusi yang akan ditawarkan untuk menjawab permasalahan yang dihadapi peternak.

3. Penentuan target peserta. Dilakukan koordinasi dengan ketua kelompok untuk menentukan siapa yang paling berhak untuk mengikuti pelatihan.

4. Pelaksanaan pelatihan sesi kelas. Pelatihan sesi kelas dilakukan selama 1 hari penuh dengan 4 buah materi yang disampaikan oleh para profesional.

5. Pelaksanaan pelatihan sesi praktik. Pelatihan pembuatan pakan dilakukan satu hari setelah sesi kelas dengan harapan adanya penguasaan materi sebelum dipraktikkan secara langsung.

6. Pendampingan penerapan hasil pelatihan. Pakan yang diproduksi pada sesi praktikum kemudian diproduksi dalam volume yang lebih banyak untuk diberikan secara acak kepada 
beberapa peserta pelatihan sebagai pakan sapi mereka selama 3 bulan.

\section{Hasil dan Pembahasan}

Kegiatan inti dari pelatihan ini dilaksanakan selama 2 hari namun sesi pendampingan penerapan teknologi dilaksanakan selama 3 bulan. Kegiatan inti dibagi menjadi 2 sesi, yaitu sesi pengayaan materi pada hari pertama dan sesi praktik pembuatan pakan komplit dilakukan di hari kedua.

Pada sesi pertama disampaikan 4 buah materi: materi pertama disampaikan oleh Sukarne, S.Pt., M.Si berkaitan dengan pengenalan bahan pakan ternak. Bahan pakan ternak pada dasarnya merupakan semua bahan yang dapat dimakan, dicerna, diabsorbsi, dan memiliki manfaat bagi ternak (Subekti, 2009). Materi kedua disampaikan oleh Prof. Ir. Dahlanuddin, M.Rur.Sc., Ph.D tentang Ilmu Nutrisi Ternak. Nutrisi ternak sangat penting untuk diketahui oleh para peternak sehingga dapat mengetahui apa saja jenis nutrisi pakan ternak dan berapa jumlah nutrisi yang dibutuhkan oleh setiap ternak. Kekurangan nutrisi pada pakan ternak sapi dapat mengakibatkan produktivitas sapi kurang optimal, karena untuk penambahan bobot badan sapi sangat tergantung pada kebutuhan nutrisi seperti kandungan protein kasar, bahan kering, dan sumber energi (Kasenta et al., 2017).

Materi ketiga disajikan oleh Dr. Tanda S. Panjaitan yang memaparkan tentang teknologi pakan ternak. Teknologi pakan ternak sangat penting untuk diketahui para peternak, karena limbah pertanian maupun agroindustri sebagai sumber pakan tidak dapat langsung diberikan sebagai pakan sapi. Oleh karena itu, untuk dapat menjadi pakan komplit limbah-limbah tersebut perlu diolah terlebih dahulu menggunakan teknologi pembuatan pakan ternak. Menurut Mayulu \& Suhardi, (2015), amoniasi dan fermentasi adalah salah satu perlakukan yang dapat diterapkan dalam mengolah limbah pertanian dan agroindustri menjadi pakan ternak sehingga palatabilitas, ketersediaan NPN dan kecernaan limbah pertanian dapat meningkat. Materi terakhir ditutup dengan pengulasan tentang formulasi pakan komplit yang disampaikan oleh Tarmizi, S.Pt. Dalam membuat formulasi pakan ternak harus disesuaikan dengan kebutuhan nutrisi ternak dan ketersediaan biaya, karena pakan masih merupakan komponen biaya terbesar dalam usaha peternakan yaitu sekitar 67,48 persen atau 60-70 persen (Wida, 2008; Hudori et al., 2020).

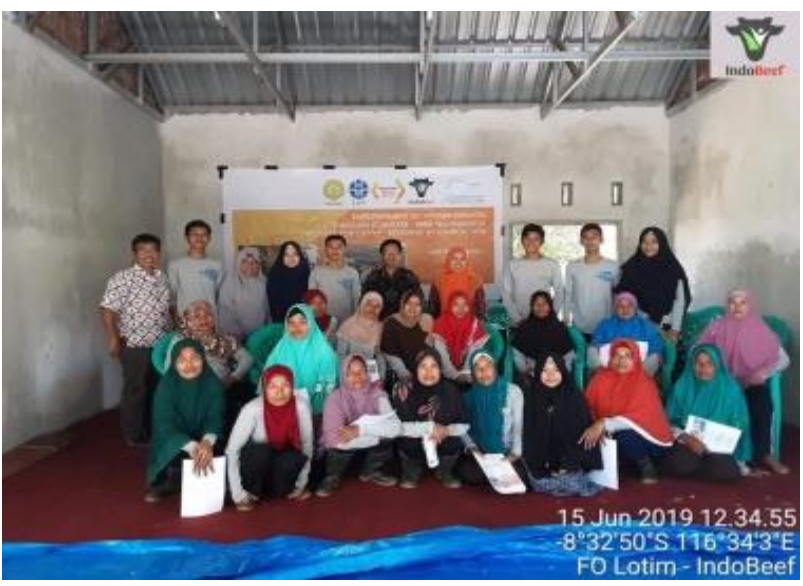

Gambar 1. Sesi penyampaian materi di kelas

Pada sesi berikutnya dilakukan praktik pembuatan pakan komplit yang dipandu langsung oleh Sukarne, S.Pt.,M.Si dan Tarmizi, S.Pt. Sesi ini dimulai dengan mempersiapkan alat dan bahan yang digunakan dalam praktikum. Peralatanperalatan yang mereka persiapkan adalah: Mesin chopper, mesin mixer, hummer mill, sekop, terpal dan alat jahit karung (untuk pengemasan). Adapun bahan bahan yang disiapkan adalah: Rumput gajah, dedak, kulit kacang tanah, lamtoro, turi, tumpi jagung, garam, urea, proaminosin dan mineralmix. Setelah bahan pakan siap kemudian mereka mulai menchopper pakan rumput gajah kemudian dijemur untuk mengurangi kadar airnya. Setelah itu, para peserta memperkecil partikel beberapa bahan menggunakan hummer mill, seperti lamtor dan turi yang telah dikeringkan dengan dijemur sebelumnya. Setelah itu, semua bahan ditimbang berdasarkan fomulasi pakan yang telah dibuat.

Tabel 1. Formulasi pakan komplit

\begin{tabular}{llc}
\hline No & \multicolumn{1}{c}{ Nama Bahan } & Level(\%) \\
\hline 1 & Jagung & 5 \\
2 & Dedak Halus & 20 \\
3 & Rumput Gajah & 35 \\
4 & Daun Lamtoro & 15 \\
5 & Kulit Kacang Tanah & 10 \\
6 & Tumpi jagung & 10 \\
\hline
\end{tabular}




\begin{tabular}{lll}
\hline 7 & Garam & 0,5 \\
8 & Urea & 0,5 \\
9 & Proaminosin & 3,5 \\
10 & Mineral & 0,5 \\
\hline
\end{tabular}

Jumlah
Semua bahan pakan yang sudah sesuai dengan formulasi kemudian dicampurkan dengan alat pencampur. Setelah pakan komplit tercampur rata kemudian dikemas kedalam karung berlapis kantong plastik kemudian dijahit.

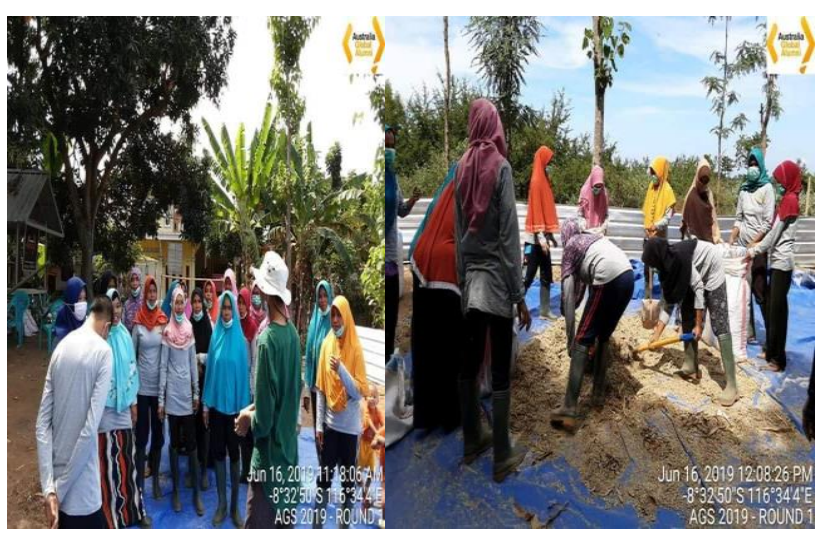

Gambar 2. Pengarahan dan Praktik Pembuatan Pakan Komplit

Setelah semua proses pembuatan pakan komplit selesai dilaksanakan, kemudian dilakukan uji coba pemberian pakan pada beberapa sapi yang ada di sekitar SPR Ridho Ilahi. Uji coba ini bertujuan untuk mengetahui tingkat palatabilitas (kesukaan) pakan komplit yang telah dibuat.

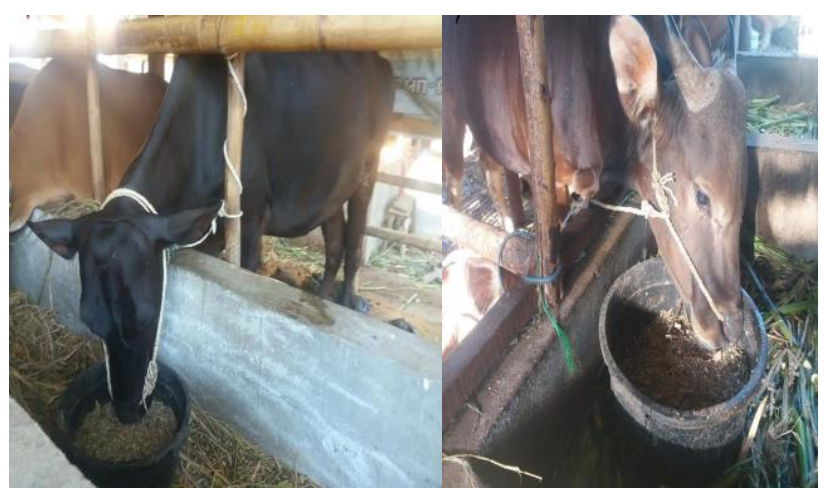

Gambar 3. Uji coba palatabilitas pakan pada ternak sapi

Setelah sesi praktik selesai dilakukan produksi pakan komplit dalam jumlah banyak untuk dibagikan ke beberapa peserta untuk diuji coba pada ternaknya selama tiga bulan. Ternak yang menjadi objek uji coba tersebut kemudian ditimbang untuk memperoleh pertambahan bobot badan harian sapi akibat dari pemberian pakan komplit tersebut. Dari hasil penimbangan diperoleh nilai rata-rata kenaikan bobot badan harian sapi sebesar $0,42 \mathrm{~kg} / \mathrm{ekor} / \mathrm{hari}$.

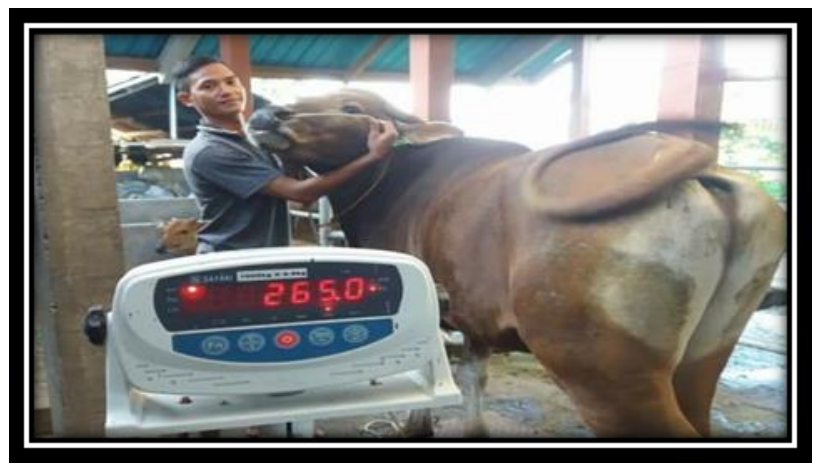

Gambar 4. Penimbangan bobot badan sapi

\section{Kesimpulan}

Para peternak perempuan memperoleh pengetahuan dan keterampilan dalam memproduksi pakan komplit secara mandiri. Dari segi kapasitas, peternak mampu memelihara sebanyak minimal 5 ekor sapi. Sedangakan dari segi produktivitas, pertambahan bobot badan harian $(\mathrm{PBBH})$ ternak rata-rata $0,42 \mathrm{~kg} / \mathrm{hari}$.

\section{Ucapan Terima Kasih}

Ucapan terima kasih disampaikan kepada Alumni Grant Scheme (Australia Awards) yang telah mendanai kegiatan ini dan KRRB UNRAM serta Indobeef yang telah membantu kelancaran pelaksanaan pelatihan.

\section{Daftar Pustaka}

Baba, S., Dagong, M. I., Ako, A., Sanusi, A., \& Muktiani, A. (2012). Produksi Complete Feed Berbahan Baku Lokal dan Murah Melalui Aplikasi Participatory Technology Development Guna Meningkatkan Produksi Dangke Susu di Kabupaten Enrekang. Prosiding InSINas, 324-330.

Dumont, B., Andueza, D., Niderkorn, V., Lüscher, A., Porqueddu, C., \& Picon-Cochard, C. (2017). Effects of climate change on forage quality of grasslands and their use by grazing 
animals. $\quad H A L, \quad 17, \quad 01611403$. https://hal.archives-ouvertes.fr/hal-01611403

Hudori, H. A., Rujito, H., Muksin, Pratama, F. E. A., \& Andini, P. (2020). Formulasi Ransum Alternatif Untuk Meningkatkan Efisiensi Usaha Peternakan Sapi Perah (Studi Kasus Pada Peternakan Bestcow Farm Jember). Jurnal Ilmu Peternakan Terapan, 3(2), 67-73.

Kandalam, G., \& Samireddypalle, A. (2015). Impact of Climate Change on Forage Availability for Livestock. https://doi.org/DOI:10.1007/978-81-3222265-1_7

Kasenta, A. M., Aini, L. N., \& Riyanto. (2017). Manajemen Penggemukan Sapi Brahman Cross Bx di PT. Fortuna Megah Perkasa Bogor, Jawa Barat. Jurnal Inovasi Pertanian, 1(8), 49-54.

Mayulu, H., \& Suhardi, S. (2015). Nutrient potency of rice straw processed with amofer as cattle feed stuff in East kalimantan. International Journal of Science and Engineering, 9(2), 101-105.

https://doi.org/https://doi.org/10.12777/IJSE.9 .2.101-105

Mukminah, N., Destiana, I. D., Rahayu, W. E., \& Sobari, E. (2019). Inovasi Teknologi Pakan Komplit (Complete Feed) Sapi Potong Berbasis Limbah Agroindustri di Kabupaten Subang. Jurnal Pengabdian Kepada Masyarakat MEDITEG, 4(1), 33-42.

Nursan, M., \& Septiadi, D. (2020). Penentuan Prioritas Komoditas Unggulan Peternakan di Kabupaten Sumbawa Barat. Jurnal Agribisnis Dan Ilmu Sosial Ekonomi Pertanian, 5(1), 29-34.

Sari, M. (2016). Pemanfaatan Limbah Jagung Untuk Pembuatan Biskuit Pakan Hijauan di Kecamatan Lima Kaum Batusangkar. Journal of Sainstek, 8(2), 166-172.

Subekti, E. (2009). Ketahanan Pakan Ternak Indonesia. MEDIAGRO, 5(2), 63-71.

Utari, F. ., Prasetiyono, B. W. H. ., \& Muktiani, A. (2012). Kualitas Susu Kambing Peranakan Ettawa yang diberi Suplementasi Protein Terproteksi dalam Wafer Pakam Komplit Berbasis Limbah Agroindustri. Animal Agriculture Journal, 1(1), 427-441.

Wida, E. (2008). Formulasi Kombinasi Optimum Faktor-faktor Produksi Usaha Peternakan Sapi Perah Rakyat di Kabupaten Boyolali. Sains
Peternakan: Jurnal Penelitian Ilmu Peternakan, 6(2), 31-44. 